\title{
Perilaku Menjaga Kebersihan Organ Genitalia pada Konsumen Pembalut Herbal
}

\author{
Putri Sasmita Wati, Mury Ririanty, Iken Nafikadini ${ }^{1}$ \\ Fakultas Kesehatan Masyarakat, Universitas Jember, Indonesia ${ }^{1}$ \\ e-mail: mitaputri500@gmail.com
}

\begin{abstract}
Sanitary napkins are disposable products that are commonly used by women every month.The use of sanitary napkins in women still provides the risk of various health problems. In 2015 the Indonesian Consumers Foundationalso known as YLKI announced 9 brands of sanitary napkins containing dioxin. Dioxins derived from the bleaching process and are carcinogenic substances that are harmful to genitalian organs. Herbal sanitary napkins are innovations of healthy sanitary napkins chosen by Indonesian women as an effort to maintain the cleanliness of genitalia organs. Jember Regency is the third highest region in East Java which has the highest level of herbal sanitary consumers in 2018. This study aimed to describe the behavior of maintaining the cleanliness of genitalia organs in consumers of herbal sanitary napkins in Jember Regency. The study method was quantitative descriptive with 125 samples taken from 15 active distributors in Jember Regency. Data collection was done by questionnaire and observation. The results of the study were $56 \%$ of the respondents 'knowledge was good, 58\% of the respondents had a positive attitude and $71 \%$ of the respondents' actions were in the good category. As many as $94 \%$ of respondents were influenced by distributors, $80 \%$ were influenced by biological mothers, $75 \%$ were influenced by friends and $16 \%$ were influenced by mother-in-law. Observations on the types of sanitary napkins used, 91\% of day users, 65\% of pantyliner users, 58\% of night use users. As much as $100 \%$ of the water in the respondent's bathroom was in good condition, and as many as $71 \%$ of respondents had used cotton underwear. Recommendation for consumers is they should completely know about the efficacy and content of the herbal sanitary napkins. For companies, they should provide the user appeal of sanitary napkin packages and provide the offline and online health consultation hotline through social media.
\end{abstract}

Keywords : behavior, hygiene of genitalia, herbal sanitary napkins

\section{Pendahuluan}

Kesehatan genitalia merupakan salah satu pemasalahan organ reproduksi yang sering di alami wanita diberbagai negara termasuk di Indonesia. Data studi kesehatan dunia (WHO) menunjukkan angka kejadian masalah genitalia pada wanita telah mencapai $33 \%$ dari jumlah total beban penyakit yang diderita wanita di dunia (Putra, 2011). Sebanyak 50\% penyebab masalah genitalia disebabkan oleh penggunaan pembalut yang kurang tepat (Ross, 2014). Pembalut wanita merupakan produk sekali pakai yang biasa digunakan wanita setiap bulannya (Kumalasari, 2016). Perilaku higienitas wanita yang kurang saat menggunakan pembalut dapat menjadi faktor risiko timbulnya penyakit. Saat ini banyak wanitadi Indonesia yang memilih menggunakan produk pembalut herbal untuk kebutuhan menstruasinya.

Pembalut herbal merupakan salah satu jenis pembalut yang telah didistribusikan di seluruh wilayah di
Indonesia. Kabupaten Jember merupakan salah satu wilayah penjualan tertinggi ketiga di Jawa Timur. Produsen pembalut herbal pertama kali memasarkan produknya di Kabupaten Jember tahun 2009 kemudian vakum di tahun 2013-2015. Tahun 2015 akhir peminat pembalut herbal di Kabupaten Jember semakin meningkat dan kini telah memiliki 1 agen center dan 15 distributor resmi aktif yang tersebar di seluruh wilayah di Kabupaten Jember. Data penjualan center Jember menunjukkan, terdapat 458 wanita konsumen aktif yang menggunakan pembalut herbal setiap bulannya. Pengelola juga telah aktif mengadakan seminar untuk memonitoring penjualan dan melakukan edukasi bagi distributor baru dalam upaya menunjang penawaran produk pada konsumen.

Teori WHO menyatakan bahwa seseorang dapat berperilaku karena adanya 4 alasan pokok yang mempengaruhi. Determinan tersebut yaitu, pemikiran dan perasaan (thought and feeling), adanya 
acuan atau referensi yang dipercayai (personal refrences), sumber daya (resoursces), dan sosio budaya (culture). Pengetahuan, sikap, orang penting sebagai referensi dan sumber daya yang dimiliki oleh wanita berpengaruh dalam menentukan status tindakan wanita sebagai pengguna pembalut herbal sebagai upaya menjaga kebersihan organ genitalia. Perilaku pemilihan produk pembalut juga dipengaruhi oleh pengetahuan konsumen calon pemakai produk (Rimawati, 2012).

Hasil studi pendahuluan pada distributor menyatakan bahwa masih adanya anggapan semakin lama penggunaan pembalut herbal, maka semakin dirasakan khasiat positifnya bagi kesehatan. Selain itu, masih banyak ditemukan bahwa pembalut herbal digunakan sebagai pengobatan utama dalam mengatasi keluhan kesehatan yang diderita. Berdasarkan fenomena tersebut peneliti tertarik untuk melakukan penelitian yang berjudul perilaku menjaga kebersihan organ genitalia pada konsumen pembalut herbal di Kabupaten Jember.

\section{Metode}

Penelitian ini menggunakan jenis penelitian kuantitatif dengan pendekatan deskriptif. Populasi penelitian adalah 458 konsumen pembalut herbal dengansampel sebanyak 125 responden.

\subsection{Metode Pengumpulan Data}

Pengambilan subjek penelitian dilaksanakan berdasarkan populasi yang disesuaikan dengan kriteria eksklusi dan inklusi yang ditetapkan oleh peneliti. Teknik sampling pada penelitian ini yaitu dengan teknik sampling proportional sampling. Penelitian dilaksanakan di Kabupaten Jember yang merupakan wilayah tertinggi ketiga di Jawa Timur yang memiliki tingkat konsumen pembalut herbal tertinggi. Teknik pengumpulan data menggunakan wawancara berdasarkan lembar kuesioner, observasi dan dokumentasi untuk memperoleh data primer dalam penelitian ini.

\subsection{Metode Analisis Data}

Teknik analisis data yang dilakukan menggunakan uji univariat SPSS sebagai hasil interpretasi wawancara kuesioner yang dijabarkan dalam bentuk uraian dan tabel.

\section{Hasil dan Pembahasan}

Pengetahuan merupakan hasil pengalaman seseorang dalam proses menjalani kehidupan. Hasil penelitian mengenai pengetahuan cara menjaga kebersihan organ genitalia disajikan dalam tabel 1.

Tabel 1 menunjukkan hasil penelitian dimana sebanyak 70 responden atau 56\% responden telah memiliki pengetahuan yang baik tentang cara menjaga kebersihan organ genitalia. Tabel 1 menampilkan perhitungan kuesioner pengetahuan tentang lima indikator menjaga kebersihan organ genitalia yang telah dijawab responden:

Tabel 1. Deskripsi Pengetahuan Cara Menjaga Kebersihan Organ Genitalia

\begin{tabular}{|c|c|c|c|c|c|}
\hline $\mathbf{N}$ & \multirow{2}{*}{ Pernyataan } & \multicolumn{2}{|c|}{ Benar } & \multicolumn{2}{|c|}{ Salah } \\
\hline No & & $\mathbf{n}$ & $\%$ & & $\%$ \\
\hline 1 & $\begin{array}{l}\text { Kesehatan genitalia adalah kesehatan yang berhubungan dengan } \\
\text { sehatnya sistem organ kewanitaan sesuai fungsinya }\end{array}$ & 125 & 100 & 0 & 0 \\
\hline 2 & Celana dalam yang baik adalah yang diganti 2 kali sehari & 112 & 90 & 13 & 10 \\
\hline 3 & $\begin{array}{l}\text { Gangguan pada vagina dapat diakibatkan dari penggunaan kamar } \\
\text { mandi }\end{array}$ & 30 & 24 & 95 & 76 \\
\hline 4 & $\begin{array}{l}\text { Gangguan genitalia tidak berkaitan dengan proses membasuh } \\
\text { vagina setelah berhubungan seksual }\end{array}$ & 47 & 38 & 78 & 62 \\
\hline 5 & $\begin{array}{l}\text { Pembalut kecil (pantyliner) yang baik adalah pembalut yang } \\
\text { berparfum }\end{array}$ & 31 & 25 & 94 & 75 \\
\hline 6 & $\begin{array}{l}\text { Pantyliner dapat digunakan pada saat keputihan dan pasca } \\
\text { menstruasi saja }\end{array}$ & 27 & 22 & 98 & 78 \\
\hline
\end{tabular}




\begin{tabular}{|c|c|c|c|c|c|}
\hline \multirow{2}{*}{ No } & \multirow{2}{*}{ Pernyataan } & \multicolumn{2}{|c|}{ Benar } & \multicolumn{2}{|c|}{ Salah } \\
\hline & & n & $\%$ & $\mathbf{n}$ & $\%$ \\
\hline 7 & $\begin{array}{l}\text { Tangan harus dicuci saat sebelum dan sesudah menggunakan } \\
\text { pembalut }\end{array}$ & 104 & 83 & 21 & 17 \\
\hline 8 & $\begin{array}{l}\text { Pembalut herbal dapat digunakan lebih lama dibanding pembalut } \\
\text { biasa }\end{array}$ & 87 & 70 & 38 & 30 \\
\hline 9 & $\begin{array}{l}\text { Masalah genitalia dapat diatasi dengan antibiotik pada pembalut } \\
\text { herbal }\end{array}$ & 115 & 92 & 10 & 8 \\
\hline 10 & $\begin{array}{l}\text { Pergantian pembalut dapat dilakukan setelah pembalut penih } \\
\text { darah }\end{array}$ & 83 & 66 & 42 & 34 \\
\hline 11 & $\begin{array}{l}\text { Membasuh vagina yang benar dilakukan dari arah depan ke } \\
\text { belakang }\end{array}$ & 58 & 46 & 67 & 54 \\
\hline 12 & Pembalut adalah produk yang tidak memiliki tanggal kadaluarsa & 28 & 22 & 97 & 78 \\
\hline 13 & Vagina lebih aman dibasuh menggunakan air mengalir & 111 & 89 & 14 & 11 \\
\hline 14 & $\begin{array}{l}\text { Pembalut herbal dan pembalut biasa memiliki komposisi yang } \\
\text { sama }\end{array}$ & 11 & 9 & 114 & 91 \\
\hline
\end{tabular}

Tabel 2 menunjukkan indikator cara menjaga kebersihan organ genitalia yang kurang dalam variabel pengetahuan adalah penggunaan pantyliner sesuai kebutuhan sebanyak 78\%, frekuensi penggantian pembalut herbal sebanyak $70 \%$, penggunaan toilet sebanyak $76 \%$, dan cara membasuh organ genitalia yang benar sebanyak 54\%.

\subsection{Sikap dalam Menjaga Kebersihan Organ Genitalia}

Sikap merupakan respon tertutup seseorang

kurang dalam variabel sikap adalah

indikator penggunaan kloset duduk sebanyak 54\%, membersihkan organ genitalia setelah berhubungan seksual sebanyak 55\%, penggunaan pantyliner terhadap stimulus yang telah diterima. Hasil penelitian menunjukkan sebanyak 73 responden atau $58 \%$ responden telah memiliki sikap yang positif tentang cara menjaga kebersihan organ genitalia. Berikut hasil perhitungan kuesioner sikap tentang lima indikator menjaga kebersihan organ genitalia yang telah dijawab responden disajikan dalam Tabel 3.

Tabel 3. menunjukkan indikator cara menjaga keberihan organ genitalia yang

pada

sesuai kebutuhan sebanyak $70 \%$ dan frekuensi pergantian pembalut herbal sebanyak $48 \%$.

Tabel 2. Deskripsi Sikap Cara Menjaga Kebersihan Organ Genitalia

\begin{tabular}{|c|c|c|c|c|c|}
\hline \multirow{2}{*}{ No } & \multirow{2}{*}{ Pertanyaan } & \multicolumn{2}{|c|}{ Setuju } & \multicolumn{2}{|c|}{ Tidak setuju } \\
\hline & & $\mathrm{N}$ & $\%$ & $\mathrm{~N}$ & $\%$ \\
\hline 1 & Kebersihan genitalia penting untuk dijaga & 125 & 100 & 0 & 0 \\
\hline 2 & Celana dalam saya diganti minimal dua kali sehari & 96 & 77 & 29 & 23 \\
\hline 3 & Kloset duduk digunakan karena lebih bersih dan nyaman & 67 & 54 & 58 & 46 \\
\hline 4 & $\begin{array}{l}\text { Organ kewanitaan saya dibasuh dari belakang ke depan setelah } \\
\text { BAB dan BAK }\end{array}$ & 59 & 47 & 66 & 53 \\
\hline 5 & Saya akan langsung tidur setelah melakukan hubungan seksual & 69 & 55 & 56 & 45 \\
\hline 6 & $\begin{array}{l}\text { Pantyliner dapat digunakan meskipun tidak mengalami } \\
\text { keputihan dan pasca menstruasi }\end{array}$ & 87 & 70 & 38 & 30 \\
\hline 7 & Patyliner berparfum digunakan karena lebih harum dan nyaman & 31 & 25 & 94 & 75 \\
\hline 8 & $\begin{array}{l}\text { Saya akan membeli pembalut herbal karena kandungan } \\
\text { antibiotiknya bermanfaat bagi kesehatan genitalia saya }\end{array}$ & 100 & 80 & 25 & 20 \\
\hline 9 & Pembalut saya diganti setelah 4 jam pemakaian & 65 & 52 & 60 & 48 \\
\hline 10 & Pembalut herbal saya gunakan karena harganya lebih mahal & 22 & 18 & 103 & 82 \\
\hline 11 & $\begin{array}{l}\text { Saya akan mencuci tangan sebelum dan sesudah mengganti } \\
\text { pembalut }\end{array}$ & 94 & 75 & 31 & 25 \\
\hline
\end{tabular}




\begin{tabular}{|c|c|c|c|c|c|}
\hline \multirow{2}{*}{ No } & \multirow{2}{*}{ Pertanyaan } & \multicolumn{2}{|c|}{ Setuju } & \multicolumn{2}{|c|}{ Tidak setuju } \\
\hline & & $\mathrm{N}$ & $\%$ & $\mathrm{~N}$ & $\%$ \\
\hline 12 & Semua bahan celana dalam sehat digunakan bagi wanita & 30 & 24 & 95 & 76 \\
\hline 13 & $\begin{array}{l}\text { Organ genitalia aman dibasuh menggunakan air penampungan } \\
\text { kamar mandi umum }\end{array}$ & 24 & 19 & 101 & 81 \\
\hline 14 & $\begin{array}{l}\text { Vagina harus dikeringkan sebelum menggunakan pembalut } \\
\text { kembali }\end{array}$ & 64 & 51 & 61 & 49 \\
\hline
\end{tabular}

\subsection{Personal Reference dalam Menjaga Kebersihan Organ Genitalia pada Konsumen Pembalut Herbal}

Orang penting sebagai referensi merupakan salah satu alasan seseorang berperilaku. Hasil penelitian menunjukkan bahwa distributor mempengaruhi mayoritas responden yaitu sebanyak 117 responden atau 94\%. Sebanyak 111 responden atau $89 \%$ dipengaruhi suami, 100 responden atau 80\% dipengaruhi ibu kandung, 94 responden atau $75 \%$ dipengaruhi teman dan sebanyak 20 responden $16 \%$ dipengaruhi oleh ibu mertua.

\subsection{Sumber daya dalam Menjaga Kebersihan Organ Genitalia pada Konsumen Pembalut Herbal}

Sumber daya merupakan salah satu faktor penyebab seseorang memutuskan untuk berperilaku. Hasil penelitian menunjukkanterdapat 76 responden atau $61 \%$ telah memiliki pendapatan diatas UMR Kabupaten Jember yaitu sebanyak Rp. $1.917 .000,-$. Sebanyak $100 \%$ responden telah mengalokasikan uangnya untuk melakukan upaya membersihkan organ genitalia.

\subsection{Tindakan dalam Menjaga Kebersihan Organ Genitalia pada Konsumen Pembalut Herbal}

Tindakan merupakan bentuk respon terbuka responden terhadap stimulus yang diterima. Hasil penelitian menunjukkan sebanyak 89 responden atau $71 \%$ responden telah memiliki tindakanyang baik tentang cara menjaga kebersihan organ genitalia. Tabel 3 menampilkan perhitungan kuesioner tindakan tentang lima indikator menjaga kebersihan organ genitalia yang telah dijawab responden

Tabel 3. Deskripsi Tindakan Cara Menjaga Kebersihan Organ Genitalia

\begin{tabular}{|c|c|c|c|c|c|}
\hline \multirow{2}{*}{ No } & \multirow{2}{*}{ Pernyataan } & \multicolumn{2}{|c|}{ Ya } & \multicolumn{2}{|c|}{ Tidak } \\
\hline & & $\mathrm{N}$ & $\%$ & $\mathrm{~N}$ & $\%$ \\
\hline 1 & Vagina saya dibasuh dari depan ke belakang & 91 & 73 & 34 & 27 \\
\hline 2 & Kloset harus disiram dahulu sebelum digunakan & 94 & 75 & 31 & 25 \\
\hline 3 & Saya mengganti celana dalam waktu mandi pagi saja & 28 & 22 & 97 & 78 \\
\hline 4 & $\begin{array}{l}\text { Saya lebih memilih pembalut kecil (pantyliner) yang } \\
\text { berparfum }\end{array}$ & 30 & 24 & 95 & 76 \\
\hline 5 & Vagina perlu dibasuh setelah berhubungan seksual & 27 & 22 & 98 & 78 \\
\hline 6 & Pembalut saya diganti setiap 4 jam sekali ketika menstruasi & 67 & 54 & 58 & 46 \\
\hline 7 & Pembalut kecil (pantyliner) saya gunakan ketika keputihan & 108 & 86 & 17 & 14 \\
\hline 8 & Pembalut digunakan sesuai kebutuhan & 95 & 76 & 30 & 24 \\
\hline 9 & $\begin{array}{l}\text { Pantyliner dapat digunakan setiap hari karena memberikan } \\
\text { kenyamanan. }\end{array}$ & 74 & 59 & 51 & 41 \\
\hline
\end{tabular}




\begin{tabular}{|c|c|c|c|c|c|}
\hline \multirow{2}{*}{ No } & \multirow{2}{*}{ Pernyataan } & \multicolumn{2}{|c|}{$\mathrm{Ya}$} & \multicolumn{2}{|c|}{ Tidak } \\
\hline & & $\mathrm{N}$ & $\%$ & $\mathrm{~N}$ & $\%$ \\
\hline 10 & $\begin{array}{l}\text { Saya hanya menggunakan air mengalir untuk membasuh } \\
\text { vagina saya setelah BAB dan BAK }\end{array}$ & 89 & 71 & 36 & 29 \\
\hline 11 & $\begin{array}{l}\text { Saya selalu memilih celana dalam berbahan nilon karena lebih } \\
\text { nyaman }\end{array}$ & 69 & 55 & 56 & 45 \\
\hline 12 & $\begin{array}{l}\text { Pembalut herbal aman saya gunakan kapan saja karena } \\
\text { pembalut tidak pernah kadaluarsa }\end{array}$ & 40 & 32 & 85 & 68 \\
\hline 13 & Saya selalu mengeringkan vagina saya setelah $\mathrm{BAB}$ dan $\mathrm{BAK}$ & 112 & 90 & 13 & 10 \\
\hline
\end{tabular}

Tabel 3. menunjukkan indikator cara menjaga keberihan organ genitalia yang kurang dalam variabel sikap adalah pada indicator membersihkan organ genitalia setelah berhubungan seksual sebanyak $78 \%$, penggunaan pantyliner sesuai kebutuhan sebanyak $59 \%$ dan frekuensi pergantian pembalut yang benar sebanyak $46 \%$. Hasil observasi menunjukkan jenis pembalut yang sering digunakan adalah pembalut jenis day use yaitu sebanyak 91\%, pantyliner sebanyak $65 \%$, dan night use $58 \%$. Terdapat $100 \%$ telah memiliki sumber air yang baik yaitu tidak berwarna, tidak berasa, dan tidak berbau. Terdapat $71 \%$ responden juga telah menggunakan celana dalam berbahan katun.

\subsection{Pengetahuan dalam Menjaga Kebersihan Organ Genitalia pada Konsumen Pembalut Herbal}

Higienitas menstruasi dapat dipengaruhi oleh pengetahuan seseorang tentang kesehatan organ reproduksi khususnya organ genitalia (Rimawati, 2012). Wanita yang memiliki pengetahuan kesehatan reproduksi yang rendah akan memiliki kecenderungan mengabaikan kesehatan reproduksinya dan meningkatkan risiko timbulnya tindakan yang berbahaya bagi organ genitalianya. Dari lima indikator menjaga kebersihan organ genitalia, terdapat indikator yang kurang pada variabel pengetahuan, yaitu:

1. Pengetahuan Penggunaan Pantyliner Sesuai Kebutuhan

Penggunaan pantyliner pada perempuan dapat menyebabkan peningkatan $1,5^{\prime} \mathrm{C}$ suhu pada vagina (13). Selain itu penggunaan pantyliner pada perempuan dapat memberikan risiko meningkatnya bakteri vaginosis dan kandidiasis penyebab iritasi dan keputihan pada vagina perempuan (Efendi, 2011). Penggunaan pantyliner dalam waktu yang lama akan menimbulkan kelembapan yang menjadi media tumbuhnya kuman Trichomonas vaginalis. Penggunaan pantyliner selama 6 bulan dengan frekuensi penggantian 5 jam sekali dapat menyebabkan keluarnya cairan atau lendir dari vagina lebih banyak (Julina, 2012).

2. Pengetahuan Penggunaan Pembalut yang Benar Saat Menstruasi

Hasil penelitian menunjukkan responden merasa aman menggunakan pembalut herbal dengan frekuensi lebih dari 4 jam. Frekuensi penggunaan pembalut yang baik adalah digunakan kurang lebih 4 jam sekali dan dilakukan pergantian sesering mungkin apabila saat kondisi haid sedang banyakbanyaknya. Penggunaan pembalut yang terlalu lama dapat berisiko menimbulkan keadaan lembab pada vagina.

3. Pengetahuan Penggunaan Kamar Mandi

Penggunaan kamar mandi dapat memberikan risiko penyebab masalah pada organ genitalia. Penggunaan air di toilet juga memberikan risiko berpindahnya kuman dan bakteri yang berbahaya bagi organ genitalia (Arisusilo. 2012). Penggunaan air di kamar mandi yang baik adalah dengan memanfaatkan air yang mengalir (langsung dari kran) dan lebih baik menghindari menggunakan air yang telah disediakan diember untukmembasuh vagina. Hal ini disebabkan, air ember atau penampungan air kamar mandi memiliki risiko $70 \%$ mengandung jamur candida albicans.

4. Pengetahuan Membersihkan dan Membasuh Organ Genitalia dengan Benar

Cara membersihkan dan membasuh vagina dengan benar adalah dari arah depan 
kebelakang. Hal ini bertujuan untuk menghindari masuknya bibit penyakit kedalah organ genitalia khususnya vagina. Hal ini disebabkan karena organ genitalia perempuan lebih dekat dengan anus sehingga mempermudah perpindahan kuman maupun bakteri yang berisiko menyebabkan berbagai masalah genitalia.

\subsection{Sikap dalam Menjaga Kebersihan Organ Genitalia pada Konsumen Pembalut Herbal}

Sikap merupakan reaksi tertutup seseorang terhadap obyek atau stimulus yang diterima.Sikap yang muncul dari seseorang dapat berasal dari pengalaman pribadi maupun pengalaman orang terdekatnya. Sikap juga menjadi sumber penilaian seseorang terhadap keputusan untuk mendekati atau menjauhi orang lain atau objek lain. Dari lima indikator menjaga kebersihan organ genitalia, terdapat indikator yang kurang pada variabel sikap, yaitu:

\section{Sikap dalam Penggunaan Kloset Duduk}

Dewasa ini banyak sekali rumah tangga maupun penyedia tempat umum seperti kantor, mall, dan supermarket yang menggunakan jenis toilet duduk. Pemakaian kloset duduk dapat menjadi salah satu faktor risiko menularnya virus maupun bakteri ke organ genitalia. Wanita dianjurkan membersihkan kloset duduk sebelum digunakan dengan menggunakan air dan pembersih yang ada dan dikeringkan menggunakan tissue toilet (Ross, 2014). Penggunaan kloset duduk dapat menjadi salah satu faktor risiko penularan virus dan bakteri penyebab penyakit genitalia seperti virus Human Papilloma Virus (HPV) (Kumalasari, 2016).

2. Sikap dalam Membersihkan Organ Genitalia Setelah Berhubungan Seksual

Sesuai dengan kriteria inklusi peneliti, bahwa responden peneliti adalah wanita yang telah menikah dan berusia diatas 30 tahun. Mayoritas responden menjawab akan langsung tidur setelah melakukan hubungan seksual dengan pasangan. Wanita setelah berhubunganseksual dianjurkan untuk membersihkan daerah kewanitaannya agar tidak infeksi (Aryani, 2015). Membersihkan organ kewanitaan ini sebagai bentuk pencegahan masuknya kuman dan bakteri saat proses senggama dan sebagai pencegahan penularan Infeksi Menular Seksual (IMS). Penelitian juga menjelaskan sebanyak 58,8\% ibu rumah tangga yang sering mengabaikan kegiatan cebok setelah berhubungan seksual akan berpotensi tertularIMS (Lippmann, 2017).

3. Sikap dalam Penggunaan Pantyliner sesuai Kebutuhan

Hasil penelitian menjelaskan bahwa responden merasa nyaman dengan reaksi herbal yang didapat setelah menggunakan pantyliner. Pantyliner adalah salah satu faktor penyebab masalah genitalia. Lebih lanjut, pemakaian pantyliner tidak dianjurkan digunakan setiap hari dan dipakai dalam jangka waktu yang lama (Anas, 2012). Hal ini disebabkan karena cara dan penggunaan pantyliner yang kurang tepat akan menimbulkan masalah kesehatan..

4. Sikap dalam Frekuensi Pergantian Pembalut Saat Menstruasi

Hasil penelitian menunjukkan responden cenderung mengganti pembalut sebanyak 2 kali dalam sehari saat aktivitas mandi. Hasil wawancara menunjukkan bahwa harga pembalut yang mahal juga menjadi alasan responden untuk menggunakannya lebih lama. Sedangkan wanita yang menggunakan pembalut herbal akan mendapatkan efek pengobatan dari kandungan herbal didalamnya jika digunakan sesuai kebutuhannya (Pratiwi, 2017).

\subsection{Personal Reference dalam Menjaga Kebersihan Organ Genitalia pada Konsumen Pembalut Herbal}

Orang penting sebagai referensi (personal reference) merupakan orang yang dianggap penting dan dijadikan panutan seseorang dalam berperilaku (Isnair, 2011). Orang penting sebagai referensi pada penelitian ini berasal dari keluarga (suami, ibu, dan mertua), teman dan distributor.Suami adalah bagian dari keluarga inti dari hasil perkawinan. Istri akan terhindar dari penyakit IMS apabila suami dan istri membersihkan organ genitalianya sebelum dan sesudah melakukan kopulasi atau senggama (Isnair, 2011). 
Ibu juga merupakan salah satu bagian dari keluarga inti yang dekat dengan anak. Salah satu peran ibu dalam keluarga adalah mendidik anak dan memberikan informasi mengenai fungsi dan cara menjaga kesehatan reproduksi pada anak sejak awal menstruasi (Susanti, 2018). Teman merupakan faktor pendukung lain selain keluarga yang dapat mendorong wanita untuk menjaga kebersihan organ genitalianya. Sesuai dengan pernyataan diatas, hasil penelitian menunjukkan teman sebagai salah satu faktor pendorong wanita untuk melakukan kegiatan menjaga kebersihan organ genitalia.

Distributor merupakan orang yang memberikan pertimangan pemakaian produk. Sistem penjualan menggunakan distributor dapat lebih memberikan kepercayaan dan lebih efektif mengajak wanita untuk menggunakan produk pembalut herbal sebagai cara menjaga kebersihan organ genitalia (Pratiwi, 2017).

\subsection{Sumber daya dalam Menjaga Kebersihan Organ Genitalia pada Konsumen Pembalut Herbal}

Sumber daya dapat mencakup fasilitas, uang, waktu, tenaga dan sebagainya (Notoatmodjo, 2012). Merujuk pada teori tersebut, penelitian ini akan melihat sumber daya uang dan waktu dalam mempengaruhi perilaku wanita pengguna pembalut herbal. Hasil penelitian menunjukkan bahwa mayoritas responden telah berpenghasilan diatas Upah Minimal Regional (UMR) daerah Kabupaten Jember tahun 2018 yaitu sebanyak Rp. 1.917.000,-. Hal ini diimbangi dengan tindakan responden yang tetap memperhatikan kesehatan genitalianya dengan selalu menganggarkan dana khusus untuk merawat kebersihan organ genitalianya setiap bulan. Wanita dengan penghasilan tinggi akan lebih mudah memilih jenis perawatan genitalia yang lebih aman (Ten, 2010).

\subsection{Tindakan dalam Menjaga Kebersihan Organ Genitalia pada Konsumen Pembalut Herbal}

Tindakan sering diartikan sebagai bentuk nyata dari pengetahuan dan sikap seseorang. Tindakan pada penelitian ini akan membahas terkait cara menjaga kebersihan organ genitalia pada konsumen pembalut herbal. Dari lima indikator menjaga kebersihan organ genitalia, terdapat indikator yang kurang pada variabel tindakan, yaitu:

1. Tindakan Membersihkan organ genitalia setelah berhubungan seksual

Perilaku mengacuhkan kebersihan organ genitalia khususnya rongga vagina setelah proses senggama ini dapat memberikan risiko pada vagina.Wanita yang tidak membersihkan organ genitalianya setelah berhungan seksual akan lebih berisiko mengalami permasalahan genitalia (Efendi, 2011). Hal ini disebabkan, tidak terawatnya hygiene penis yang menyebabkan adanya smegma (pelumas alami penis) pada ujung penis dan berpotensi mengendap di dalam rongga vagina. Upaya yang dapat dilakukan untuk menghindari berbagai masuknya kuman dan bakteri pasca senggama adalah dengan membasuh vagina setelah bersenggama dengan baik dan benar.

2. Tindakan dalam Frekuensi Pergantian Pembalut

Responden cenderung memiliki pengertian bahwa semakin lama penggunaan pembalut maka akan semakin merasakan khasiat herbal didalamnya. Harga pembalut yang relatif mahal 3 kali lipat dari harga pembalut biasa) juga menjadi faktor pendorong wanita untuk berhemat dalam pemakaian.Sedangkan penggunaan pembalut herbal akan efektif menurunkan 35,3\% kejadian infeksi bakteri pada Wanita Pekerja Seks (WPS) di Semarang jika digunakan dengan cara yang tepat, yaitu wanita melakukan pergantian pembalut setelah 3-4 jam pemakaian (Efendi, 2011).

3. Tindakan Penggunaan Pantyliner sesuai Kebutuhan

Hasil penelitian menunjukkan responden merasa nyaman saat menggunakanpantylinersehingga merasa penting untuk menggunakannya setiap hari. Sedangkan, penggunaan pantyliner dalam waktu yang lama akan menimbulkan kelembapan yang menjadi media tumbuhnya kuman Trichomonas vaginalis (Arisusilo. 2012). Kuman ini dapat menginfeksi vagina saat pantyliner digunakan kembali setelah proses buang air kecil. 


\section{Simpulan dan Saran \\ 4.1 Simpulan}

Terdapat 56\% konsumen pembalut herbal memiliki pengetahuan yang tinggi. Indikator yang kurangyaitu pada penggunaan pantyliner sesuai kebutuhan sebanyak $78 \%$, frekuensi penggunaan pembalut herbal sebanyak $70 \%$, penggunaan kamar mandi sebanyak $76 \%$, dan cara membasuh organ genitalia yang baik dan benar sebanyak $54 \%$. Terdapat $58 \%$ konsumen pembalut herbal telah memiliki sikap yang baik. Indikator yang kurang yaitu pada indikator penggunaan kloset duduk sebanyak 54\%, membersihkan organ genitalia setelah berhubungan seksual sebanyak 55\%, penggunaan pantyliner sesuai kebutuhan sebanyak $70 \%$, frekuensi penggunaan pembalut herbal sebanyak $48 \%$.

Sumber daya ekonomi menunjukkan terdapat $61 \%$ konsumen memiliki pendapatan di atas UMR Kabupaten Jember. Terdapat $71 \%$ wanita konsumen pembalut herbal telah memiliki tindakan yang baik. Indikator yang kurang yaitu pada indikator membersihkan organ genitalia setelah berhubungan seksual sebanyak 78\%, penggunaan pantyliner sesuai kebutuhan sebanyak 59\%, frekuensi penggunaan pembalut herbal sebanyak 46\%. Sedangkan hasil observasi menunjukkan jenis pembalut yang sering diguanakan adalah pembalut jenis day use yaitu sebanyak 91\%, pantyliner sebayak $65 \%$, dan terakhir adalah night use sebanyak $58 \%$.

\subsection{Saran}

Saran yang dapat diberikan bagi produsen pembalut herbal adalah mempertahankan dan mengembangkan strategi pemasaran yang inovatif dan menyediakan hotline konsultasi kesehatan bagi konsumen kepada ahli kesehatan secara offline disetiap kantor center di wilayah dan online via media sosial.

Konsumen diharapkan untuk tetap melakukan pengobatan medis secara menyeluruh dan dapat disertai dengan penggunaan PKA. Diharapkan untuk mengetahui khasiat, kandungan, dan cara penggunaan pembalut herbal secara lengkap terlebih dahulu sebelum memutuskan untuk menggunakan produk.

Peneliti selanjutnya dapat meneliti lebih lanjut mengenai efek penggunnaan pantyliner dan pembalut herbal dengan frekuensi penggunaan yang lama menggunakan metode kualitatif untuk mendapatkan hasil yang lebih mendalam.

\section{Daftar Pustaka}

Anas, S. 2012. Jurnal Gender dan Anak, 5(1):10. Sketsa Kesehatan Reproduksi Remaja. Diunduh di: https://ejournal.ilkom.fisipunmul.ac.id/site/wpcontent/uploads/2016/06/Jurnal\%20(0 6-14-16-04-33-41).pdf

Arisusilo. 2012. Jurnal Saintis, 1(1):116.. Kanker Leher Rahim (Cancer Cervix) sebagai Pembunuh Wanita Terbanyak di Negara Berkembang. Diunduh di: http://journal.unair.ac.id/filerPDF/jpkk4 45f60b971 full.pdf

Aryani, Mardianan, Dina. 2015. Jurnal Kesehatan Masyarakat, 10(2): 166. Perilaku Pencegahan Infeksi Menular Seksual pada Wanita Pekerja Seksual Kabupaten Tegal. Diunduh di: file:///C:/Users/Acer\%20E5421/Downloads/3377-7157-1-SM.pdf

Efendi, Ferry, dan Makhfudli. 2011. Jurnal Kedokteran. 4(1): 511. Keperawatan Kesehatan Komunitas. Jakarta: Salemba Medika.

Fadhilah. 2017. E-Jurnal Pustaka Kesehatan. Determinan Perilaku Menjaga Kebersihan Organ Reproduksi pada Wanita yan menikah Dini. Jember: Fakultas Kesehatan Masyarakat Universitas Jember. Diunduh di: http://repository.unej.ac.id/bitstream/h andle/123456789/84653/Sifana\%20A malia\%20Fadhilah\%20132110101021 $\% 20 \% 23$.pdf?sequence $=1$

Isnair dan Hasanah. 2011. Jurnal Keperawatan. 9(1): 34. Hubungan Antara Penggunaan Pantyliner dengan Kejadian Flour Albus pada Remaja 
Putri. Diunduh di: http://ejurnal.umri.ac.id/index.php/ph oton/article/download/1059/614/

Julina. 2012. Jurnal Ekonomi dan Ilmu Sosial, 11(1): 2. Analisis Perilaku Konsumen Perempuan terhadap Kesehatan Reproduksi dan Perilaku Penggunaan Pembalut. Diunduh di: http://ejournal.uin-

suska.ac.id/index.php/marwah/article/vi ew/498/478 [Diakses tanggal 29

Kumalasari, Henry, Bagoes, dan Muchlis. 2016. Jurnal Epidemiologi Komunitas.1(1): $63 . \quad$ Higiene Genitalia sebagai Faktor Risiko IMS pada Ibu Rumah Tangga di Puskesmas Bandarharjo Semarang. Diunduh di: https://ejournal2.undip.ac.id/index.ph $\mathrm{p} /$ jekk/article/view/3944/2193

Lippmann, Robbins, Barroilhet, Anderson, Sadowski, dan Boyun. 2017. MR Imaging of Cervical Cancer Magnetic Resonance Imaging Clinik of North Amerika, 25(3). Diunduh di: https://www.ncbi.nlm.nih.gov/pubmed $/ 28668164$

Luthviatin, Zulkarnain, Istiaji, dan Rohmah. 2012. Dasar-Dasar Promosi Kesehatan dan Ilmu Perilaku. Jember: UPT Penerbitan Universitas Jember.

Notoatmodjo, S. 2012. Metodologi Penelitian Kesehatan: Rineka Cipta.

Persia, Rina, dan Elizabeth. 2015. Hubungan Pemakaian dengan Kejadian Fluor Albus pada Siswi SMA di Kota Padang. Diunduh file://C:/Users/Acer\%20E5421/Downloads/284-564-1-SM.pdf

Prafitri dan Ersila. 2016. Jurnal Kebidanan. 1(1): 82. Pengaruh FC-Bio Sanitary Pad Terhadap Penurunan Intensitas Disminore. Diunduh di: https://publikasiilmiah.ums.ac.id/hand le/11617/7780
Pratiwi, Sabilu, dan Fachlevy. 2017. Jurnal Ilmiah Mahasiswa Kesehatan Masyaraka. 2(6): 2. Hubungan Pengetahuan, Stres, Penggunaan Antiseptik dan Penggunaan Pembalut dengan Kejadian Fluor Albus pada Remaja Siswi SMA Negeri 8 Kendari Tahun 2017. Diunduh di: http://ojs.uho.ac.id/index.php/JIMKES MAS/article/viewFile/2910/2194

Putra. 2011. Jurnal Psikologi.1(1): 8. Perilaku Memilih Produk Pembalutt Wanita Antara Ibu dengan Remaja Putri Ditinjau Dari Status Perikahan. Diunduh di: http://journal.unair.ac.id/downloadfullpapers03\%20Bagus,\%20Perilaku\%20Memilih \%20Produk\%20Pembalut\%20Wanita.p df

Rimawati, Kusuma, dan Sanaryati. 2012. Jurnal Visikes. 11(1): 7. Kebersihan Organ Reproduksi pada Perempuan Pedesaan di Mijen Semarang. Diunduh di: https://publikasi.dinus.ac.id/index.php /visikes/article/view/658

Rohmah, Nurjayanti dan Lestari. Tanpa Tahun. Jurnal Kebidanan.1(1): 31. Hubungan Menjaga Kesehatan Organ Reproduksi dengan Kejadian Keputihan pada Siswi Kelas XI dan XII IPA SMAN 1 SOKO Ponorogo. Diunduh di:

Ross, J. 2014. Pelvic Inflammatory Disease. Medicine. 42 (96): 2.

Suryati. 2012. Jurnal Health Quality.3(1): 59. Perilaku Kebersihan Remaja Saat Menstruasi. Diunduh di: https://www.poltekkesjakarta1.ac.id/fi 1e/dokumen/20Jurnal_Suryati_65.doc $\mathrm{x}$

Susanti, dan Pratiwi. 2018. Jurnal Kebidanan. 2(1): $35 . \quad$ Perbedaan Penggunaan Pembalut dan Pantyliner Jenis Biasa, Herbal, dan Kain dengan Kejadian Keputihan. Diunduh di: 
http://ejr.stikesmuhkudus.ac.id/index.

php/ijb/article/view/427

Ten, Varina Tjon A. 2010. Menstrual Hygiene: a Negleted Condition for the Achivement of Several Millenium Development Goalis. Europe: EEPA (Europe External Policy Advisor 